\title{
Experimental investigations of the fire behaviour of facades with EPS exposed to different fire loads
}

\author{
Christian Northe, Olaf Riese and Jochen Zehfuß \\ Technische Universität Braunschweig, Institute of Building Materials, Concrete Construction and Fire \\ Protection (iBMB) Braunschweig, Germany
}

\begin{abstract}
In context of recent fire damages to façades and the related discussion about the safety of façade systems in case of fire, there is a need for discussion about the boundary conditions and the phenomena of façade fires based on fundamental investigation. On behalf of the European Institute for Fire Protection (EIFP) four major fire tests were carried out on a flat facade with external thermal insulation composite systems (ETICS) based on polystyrene with fire loads at the ground in front of the façade [1]. The tests were conducted at the Materialprüfanstalt Dresden based in Freiberg. The tests differ to the fire tests of the German building ministers in case of different fire loads and the corner-situation of the studied façade. The four fire tests are a step in systematic investigations to study examination criteria of the fire phenomena at façades. Further experimental and numerical investigations will follow.
\end{abstract}

\section{FIRE TESTS AT IBMB}

To evaluate different fire scenarios at the base of the façade fire pre-tests were carried out at iBMB. Wood cribs are selected and tested at a façade without ETICS. These fire loads are examples of waste containers or rubbish on the street. In addition, pool fires as a liquid fire sources are used to represent for example melted EPS on a job site scenario or a burning car to represent a fire with a higher heat release rate as well. A schematic measurement plan of the test façade is shown in Fig. 1. With 40 thermocouples, the temperature distribution on the façade is measured and the heat flux density (HF1 HF5) is measured with four Gardon Gauge probes from $0.75 \mathrm{~m}$ to $2.75 \mathrm{~m}$ height. For the pool fire tests the plume temperature (M70 - M73) is measured at a height of $1 \mathrm{~m}, 2 \mathrm{~m}, 3 \mathrm{~m}$ and $4 \mathrm{~m}$ above the pool surface and moved $0.10 \mathrm{~m}$ left from the central axis. The measuring points of plume temperature are $0.70 \mathrm{~m}$ in front of the façade and the probes for heat flux density measurement are installed plane with the façade surface. The mass and the mass loss are recorded with a weighing system (MV).

\subsection{Wood cribs}

As a reference for solid fire loads wood cribs are used with a weight of $100 \mathrm{~kg}, 150 \mathrm{~kg}$ and $200 \mathrm{~kg}$. The spruce wood was prepared at humidity of $50 \%$ and an air temperature of $23^{\circ} \mathrm{C}$. The wood cribs are

This is an Open Access article distributed under the terms of the Creative Commons Attribution License 2.0, which permits unrestricted use, distribution, and reproduction in any medium, provided the original work is properly cited. 


\section{MATEC Web of Conferences}

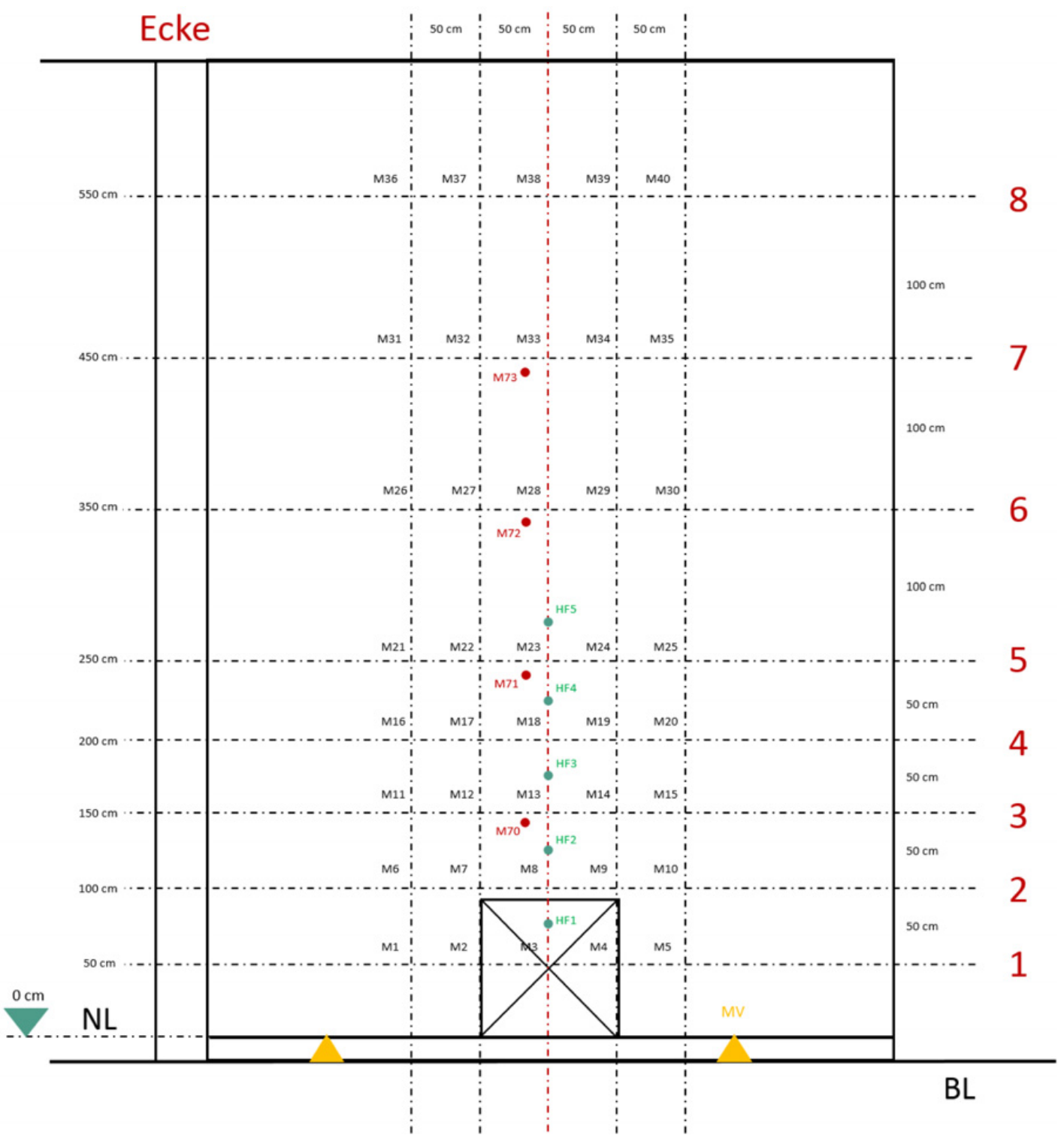

Figure 1. Experimental setup of the fire tests using the example of a wood crib.

made of single wooden sticks with an edge length of $39( \pm 2) \mathrm{mm} \times 39( \pm 2) \mathrm{mm}$ and $1.00 \mathrm{~m}$ length. The density after preconditioning is $450 \mathrm{~kg} / \mathrm{m}^{3}$. The area of each crib is $1.0 \times 1.0 \mathrm{~m}^{2}$ and the height depends on the weight and the number of used wooden sticks. To ignite the cribs $3 \times 200 \mathrm{ml}$ methanol are used.

The heat release rate (HRR) is calculated by the mass loss rate $\dot{m}^{\prime \prime}$, the caloric value $\mathrm{H}_{\mathrm{u}}$ and the combustion efficiency $\chi$ according to Eq. (1) [2].

$$
H R R=\dot{\mathrm{m}}^{\prime \prime} \cdot \mathrm{H}_{\mathrm{u}} \cdot \chi \text {. }
$$

Figure 2 shows the HRR of the three tested wood cribs. The combustion efficiency was set to 0.9 and the caloric value for wood was set to $17.28 \mathrm{MJ} / \mathrm{kg}$ [3]. The maximum values are time shifted and reaches 

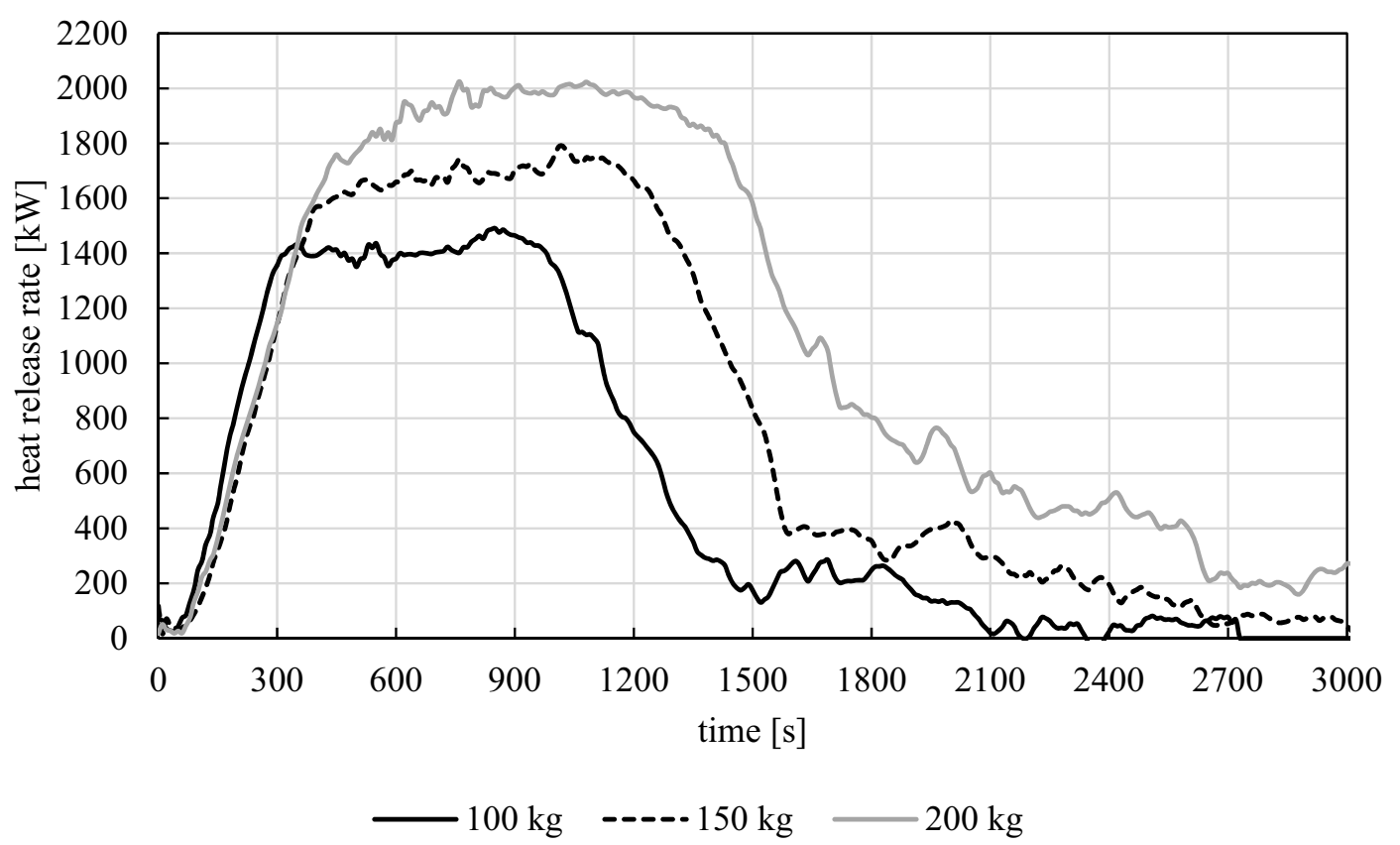

Figure 2. Heat release rate of wood cribs in the fire tests, $100 \mathrm{~kg}$ (solid black line), $150 \mathrm{~kg}$ (dashed black line), $200 \mathrm{~kg}$ (solid grey line).

from 1.4 MW for the $100 \mathrm{~kg}$ wood crib to $2.0 \mathrm{MW}$ for the $200 \mathrm{~kg}$ wood crib. The three HRR-time-curves show a similar course including the fire development, the constant combustion and the combustion abatement. According to that, Figs. 3 and 4 show a similar course of the temperature-time- and heat flux density-time-curves at the centerline of the façade surface. The temperature maximum reaches from $700^{\circ} \mathrm{C}$ for the $100 \mathrm{~kg}$ wood crib to $900{ }^{\circ} \mathrm{C}$ for the $200 \mathrm{~kg}$ wood crib. The measured heat flux density reaches time depending values of about $40 \mathrm{~kW} / \mathrm{m}^{2}$ at $1.25 \mathrm{~m}$ height above the zero line (NL).

\subsubsection{Pool fires}

Comparing to the solid fuels two liquid fuels were tested as a fire source. Both liquids, methanol and isopropanol, were tested with a volume of $2001 \mathrm{in}$ a steel pan with an area of $1.0 \times 2.0 \mathrm{~m}^{3}$ within a cooling pan with a size of $1.30 \mathrm{~m} \times 2.80 \mathrm{~m} \times 0.31 \mathrm{~m}$, made of steel as well. According to the wood crib fire tests heat flux densities and temperatures at different heights and the mass loss were measured. For ignition a burning fuse was used. The caloric value of methanol is $19.44 \mathrm{MJ} / \mathrm{kg}$ and $27.00 \mathrm{MJ} / \mathrm{kg}$ for isopropanol [3]. The HRR-time-curve of isopropanol and methanol is shown in Fig. 6. Over a period of 75 minutes the methanol reaches a HRR of about $1 \mathrm{MW}$. The isopropanol pool fire reaches a maximum HRR of about 3.5 MW and was burned out after 28 minutes. In [4] is shown that a maximum value like this is similar to the HRR of passenger cars. The combustion efficiency was set to 1.0 for liquids [3]. In the centre axis of the façade surface the temperature reaches $900{ }^{\circ} \mathrm{C}$ for isopropanol and $500{ }^{\circ} \mathrm{C}$ for methanol at a height of $1.0 \mathrm{~m}$, see Fig. 7. The measurement point M8 is $0.50 \mathrm{~m}$ above the measurement point M3 located and used because at this point a temperature maximum was recorded for the pool fires. The heat flux density reaches a value of $125 \mathrm{~kW} / \mathrm{m}^{2}$ for isopropanol and $30 \mathrm{~kW} / \mathrm{m}^{2}$ for methanol at a height of $1.25 \mathrm{~m}$. The plume temperature reaches $850^{\circ} \mathrm{C}$ for isopropanol and $350{ }^{\circ} \mathrm{C}$ for methanol at a height of $1.0 \mathrm{~m}$ above the surface of the liquid. 

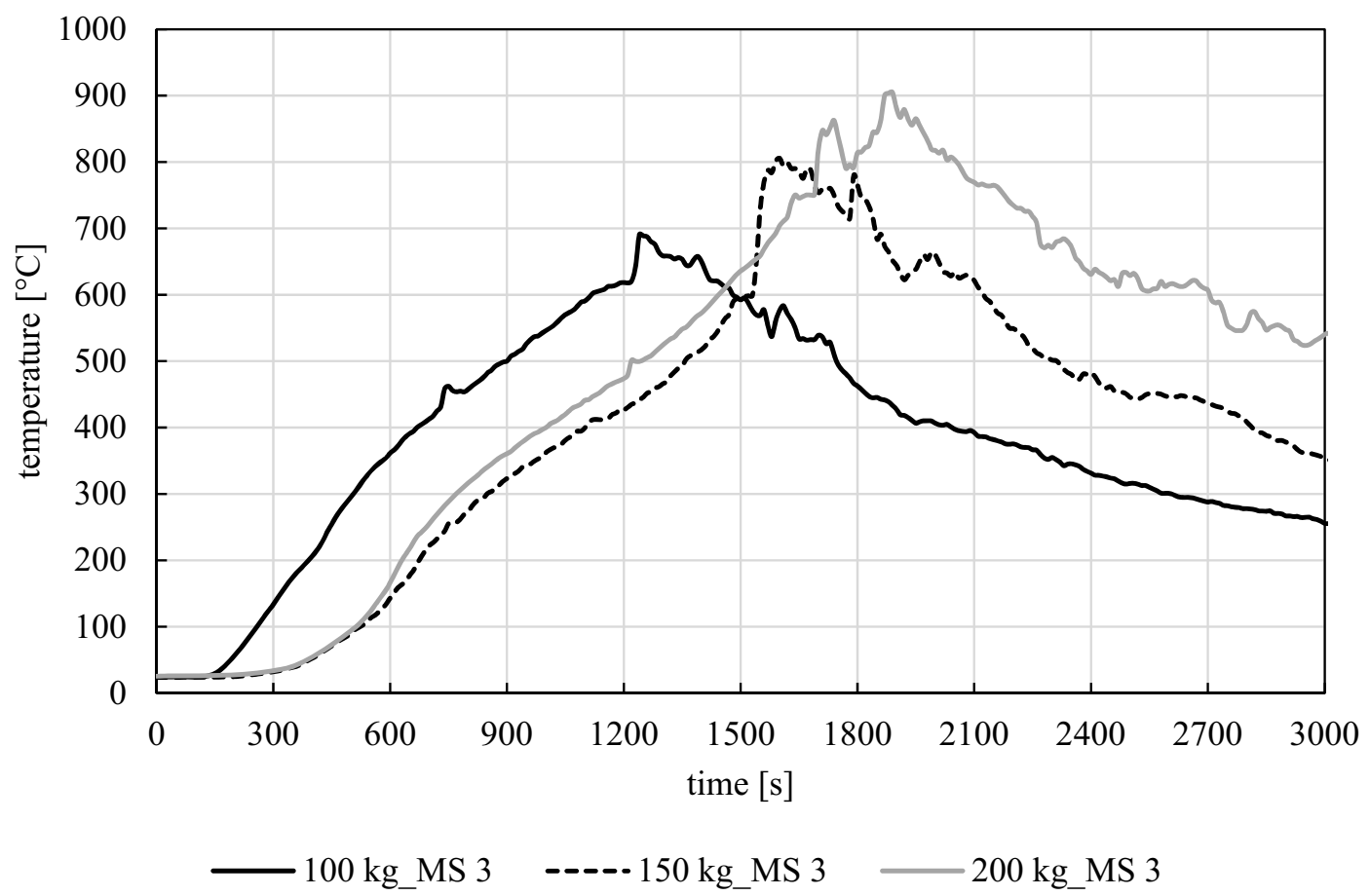

Figure 3. Comparison of the temperature-time-curves in the center axis of the façade for the fire tests at measurement point M3 at 0,50 m height, $100 \mathrm{~kg}$ (solid black line), $150 \mathrm{~kg}$ (dashed black line), $200 \mathrm{~kg}$ (solid grey line).
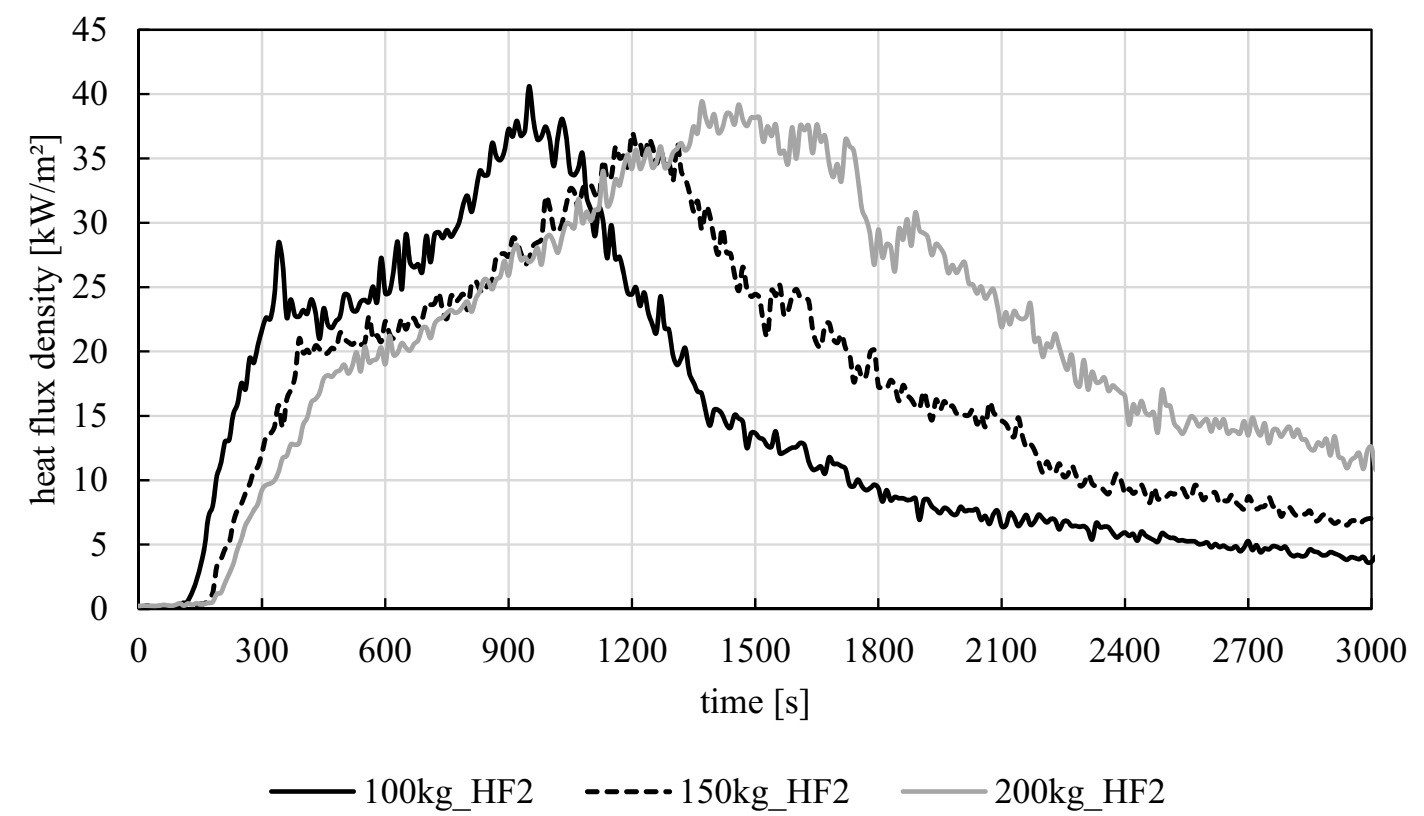

Figure 4. Comparison of heat flux density-time-curves on the façade surface for the fire tests at measurement point HF2 at $1.25 \mathrm{~m}$ height, $100 \mathrm{~kg}$ (solid black line), $150 \mathrm{~kg}$ (dashed black line), $200 \mathrm{~kg}$ (solid grey line). 

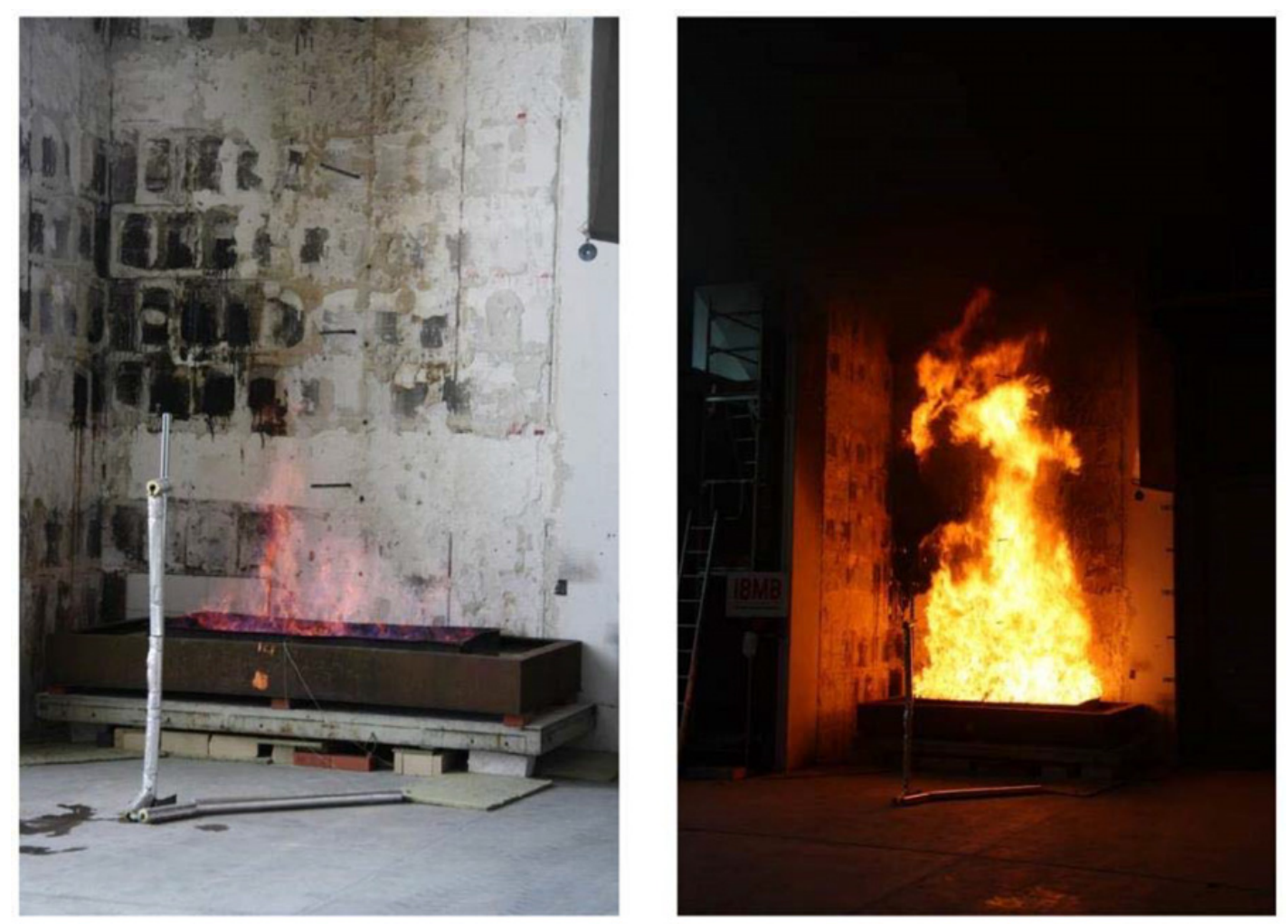

Figure 5. Fire tests with pool fires; left methanol and right isopropanol.

\section{LARGE-SCALE FIRE TESTS AT MPA DRESDEN}

The large-scale (LS) fire tests were carried out at the Materialprüfanstalt Dresden based in Freiberg. The testing façade has an area of $6 \mathrm{~m} \times 8 \mathrm{~m}(\mathrm{w} \times \mathrm{h})$ for the first and the second LS fire test and an area of $6 \mathrm{~m} \times 9 \mathrm{~m}$ for the third and fourth test, no corner and a flat surface. For the fire tests an ETICS based on XPS at the base of the façade and EPS for the remaining façade was used. Altogether four LS fire tests had taken place in the period from August 2014 to September 2015. The used EPS/XPS has a thickness of $300 \mathrm{~mm}$ on which a layer of ground plaster, a reinforcing mesh and an upper layer of plaster were applied. An overview about the main features of the four LS-fire test is shown in Table 1. A schematic overview about the measuring points is shown in Fig. 10. The measurement points for temperature are at a distance of $1 \mathrm{~m} \times 1 \mathrm{~m}$ and about $10 \mathrm{~mm}$ in front of the façade surface, number 1 to 24, type $\mathrm{NiCr}-\mathrm{Ni}$ and at a depth of $150 \mathrm{~mm}$ inside the EPS insulation, number 25 to 45 . According to the temperature measurement the wind speed and wind direction were recorded as well as the heat flux density at $4 \mathrm{~m}$ distance in front of the fire load. The first test is used as a calibration-test and the second and third tests as job site/ construction site tests. The fourth test was chosen to show the influence of holes or openings in the façade surface. The experimental conditions were not global laid down before all tests. They had always been redefined according to the latest test results. Table 2 gives an overview about all LS fire test, with comparative pictures at the same time of each test and with information's about the ETICS components after the four tests.

The first LS fire test was carried out in August 2014. The fire load was a $200 \mathrm{~kg}$ wood crib like it was used in the fire tests at iBMB. It was a flat façade with a surface area of about $8 \times 10 \mathrm{~m}^{2}$ without 


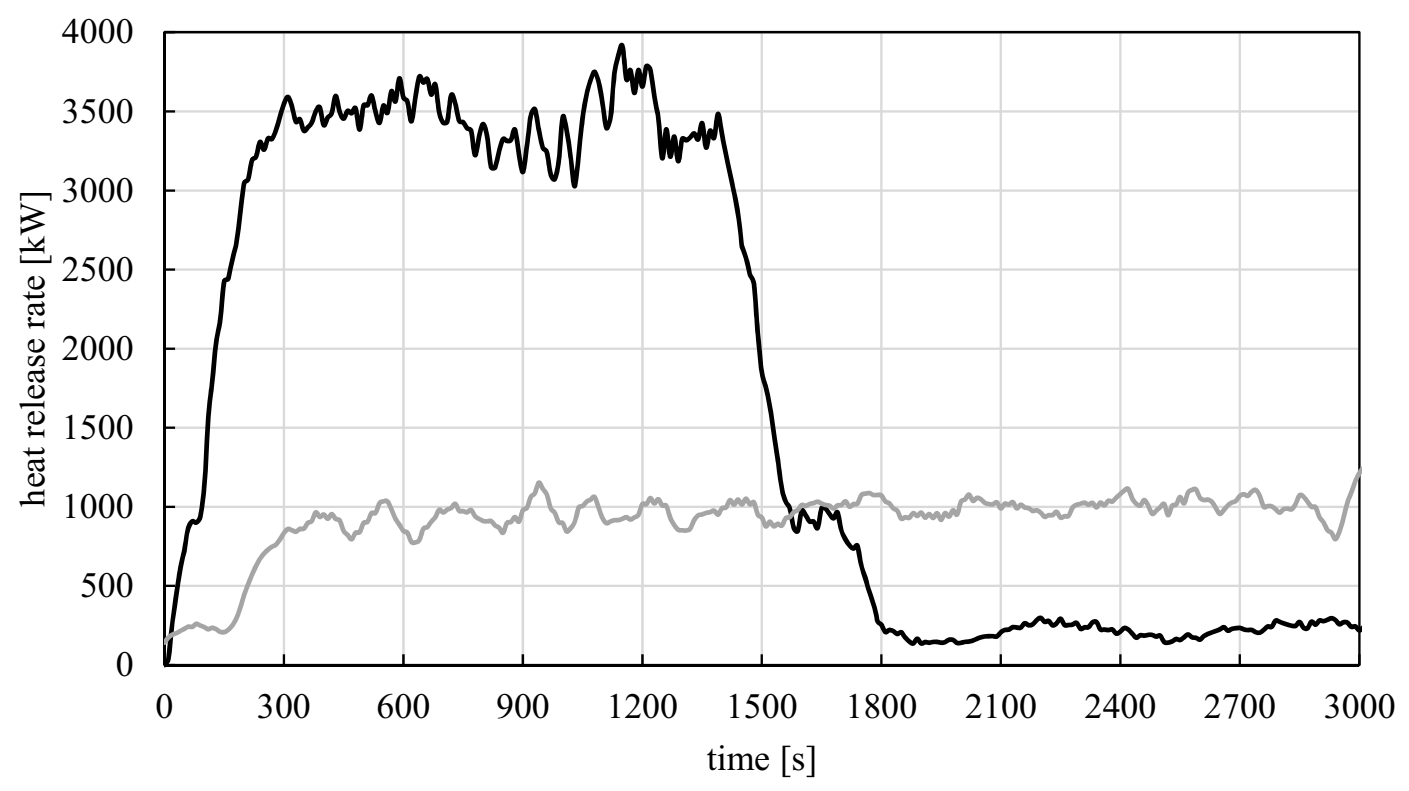

-Isopropanol - Methanol

Figure 6. Comparison of heat release rate (HRR) of isopropanol (black line) and methanol (grey line).
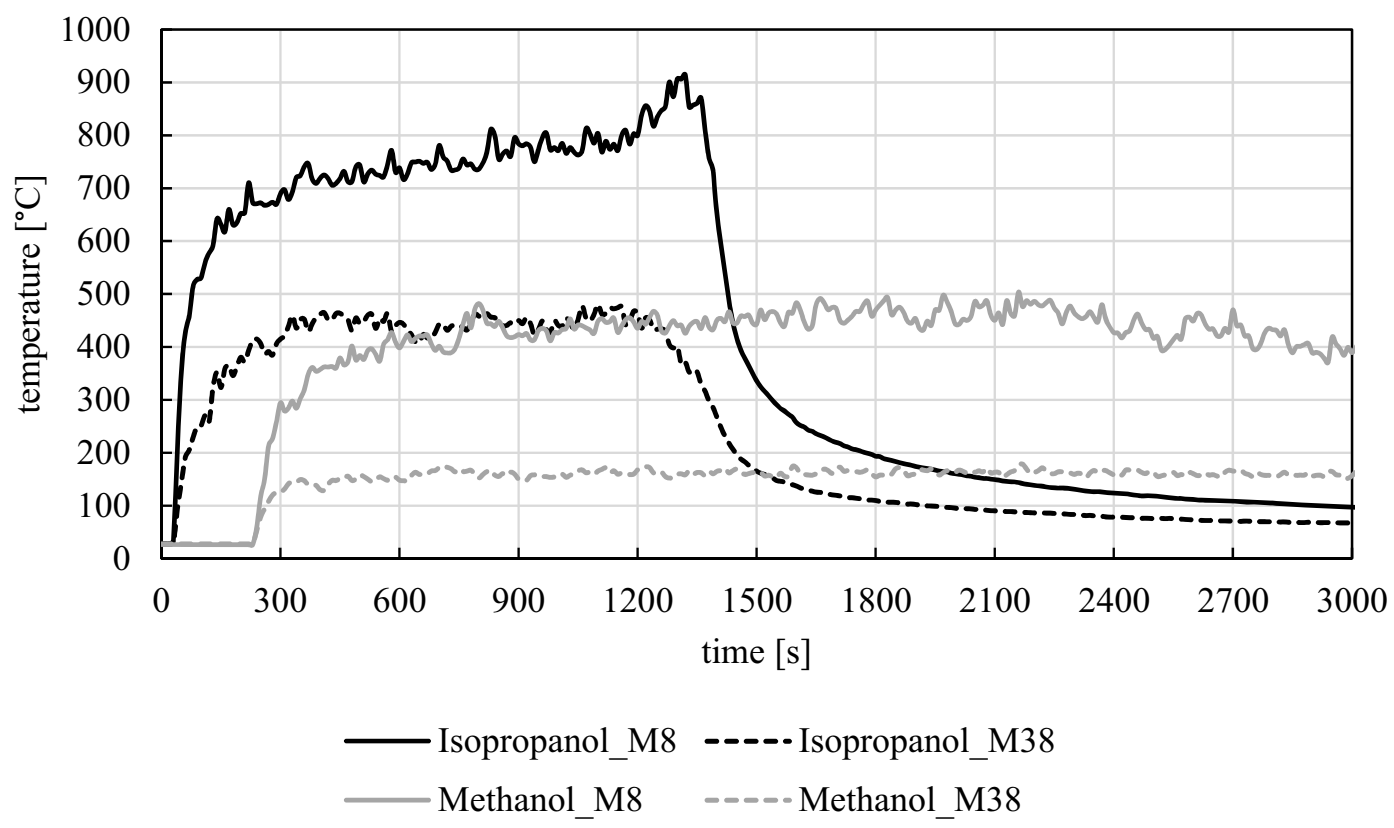

Figure 7. Comparison of temperature-time-curves at a height of $1.0 \mathrm{~m}$ (M8, bold line), $5.5 \mathrm{~m}$ (M38, dashed line) in the middle axis of façade surface for isopropanol (black lines) and Methanol (grey lines). 
$2^{\text {nd }}$ International Seminar for Fire Safety of Facades, Lund (Sweden), 2016

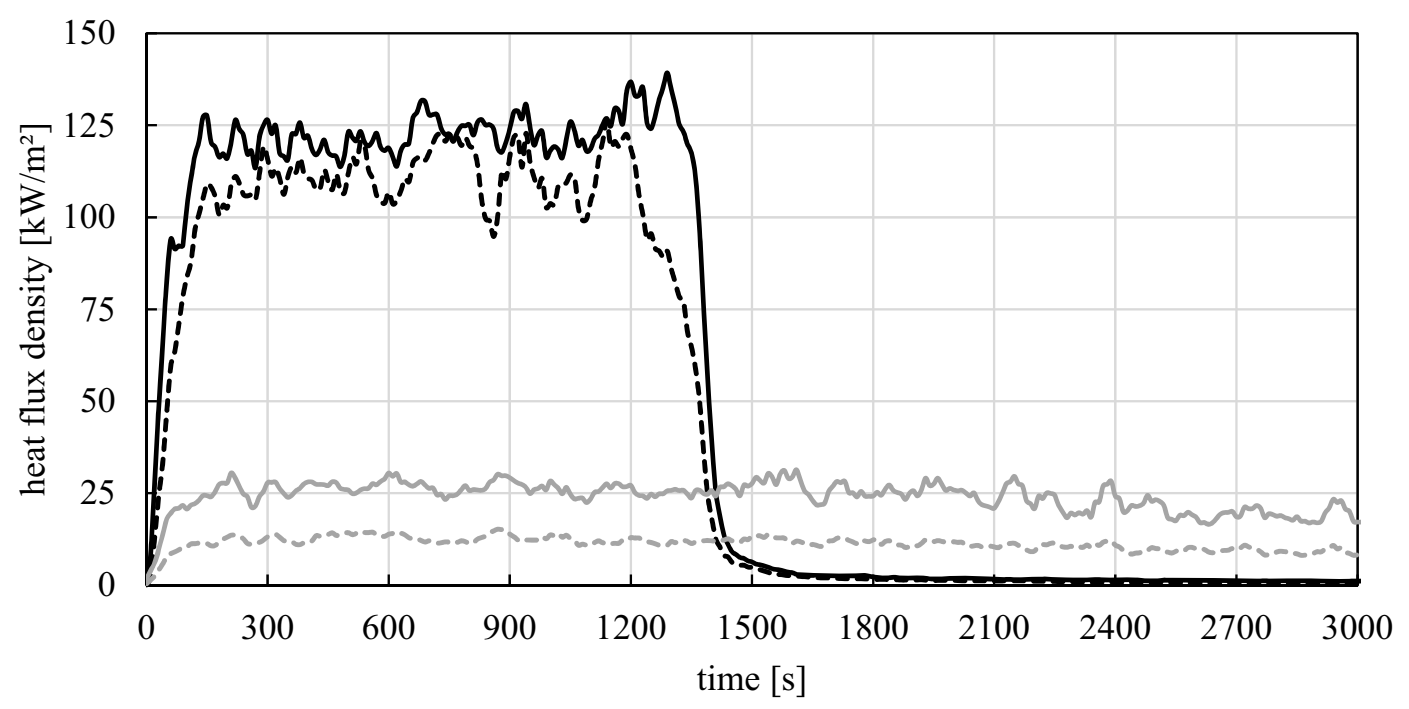

- Isopropanol_HF2------Isopropanol_HF4

Methanol_HF2_----.Methanol_HF4

Figure 8. Comparison of heat flux density-time-curves (HFD) on the façade surface for the fire tests at measurement point HF2 at $1.25 \mathrm{~m}$ height and HF4 at $2.25 \mathrm{~m}$ height for isopropanol (black lines) and methanol (grey lines).

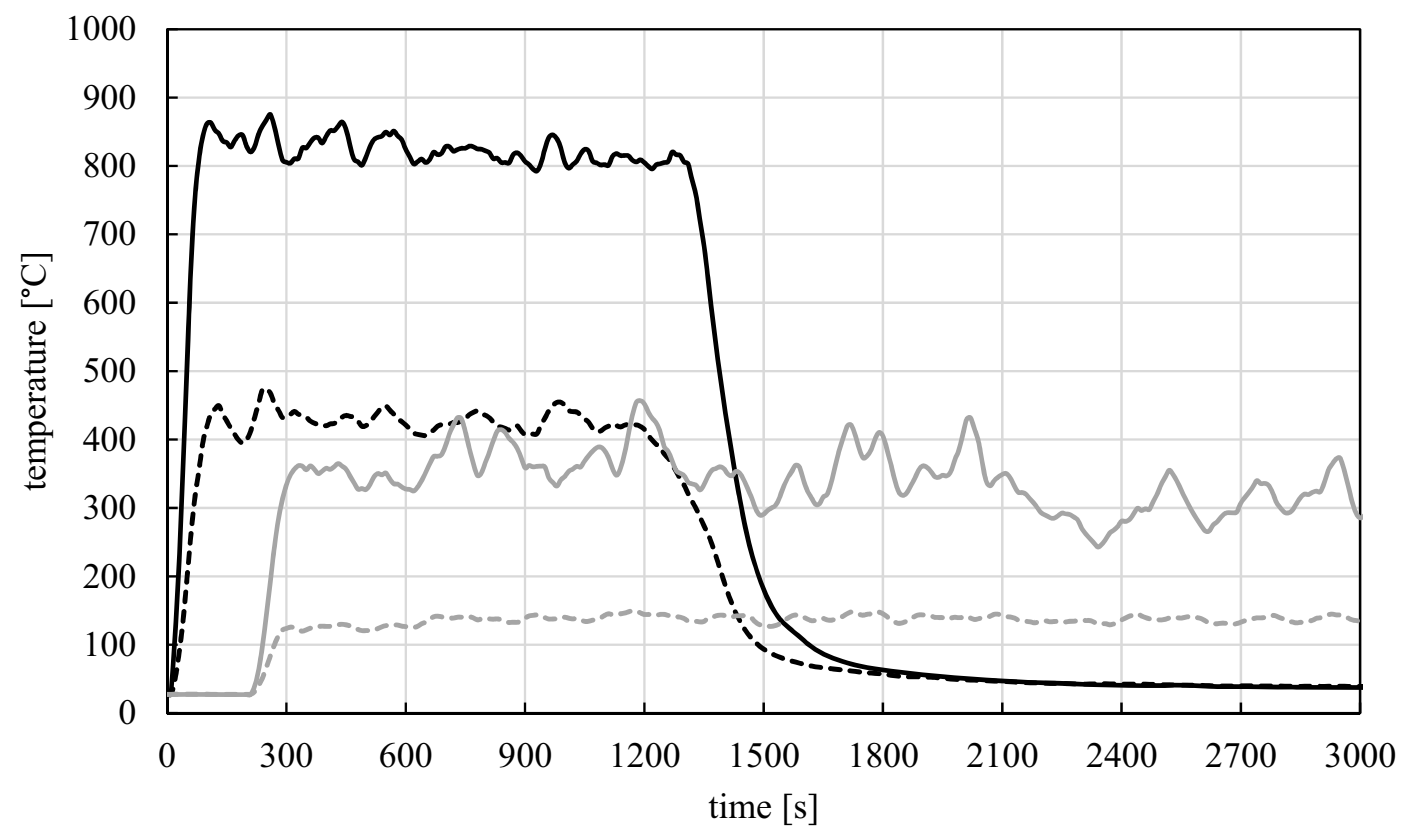

- Isopropanol M70 ------ Isopropanol M73

Methanol M70 ----- Methanol M73

Figure 9. Comparison of plume temperature-time-curves at $1.5 \mathrm{~m}$ height (M70) and $4.5 \mathrm{~m}$ height (M73) for isopropanol (black lines) and methanol (grey lines). 


\section{MATEC Web of Conferences}

Table 1. Overview about the main features of the ETICS that changed in progress.

\begin{tabular}{|l|l|l|l|l|}
\hline Comment & LS Fire Test 1 & LS Fire Test 2 & LS Fire Test 3 & LS Fire Test 4 \\
\hline Fire load & $200 \mathrm{~kg}$ wood crib & 2001 isopropanol & 2001 isopropanol & 2001 isopropanol \\
\hline HRR $[\mathrm{kW}]$ & $2000 \pm 200$ & $3500 \pm 350$ & $3500 \pm 350$ & $3500 \pm 350$ \\
\hline HFD $\left[\mathrm{kW} / \mathrm{m}^{2}\right]$ & 32 & 125 & 125 & 125 \\
\hline Fire barrier & 1 & 1 & 3 & 3 \\
\hline Openings & no & no & no & $3(1.35 \mathrm{~m} \times 1.01 \mathrm{~m})$ \\
\hline
\end{tabular}
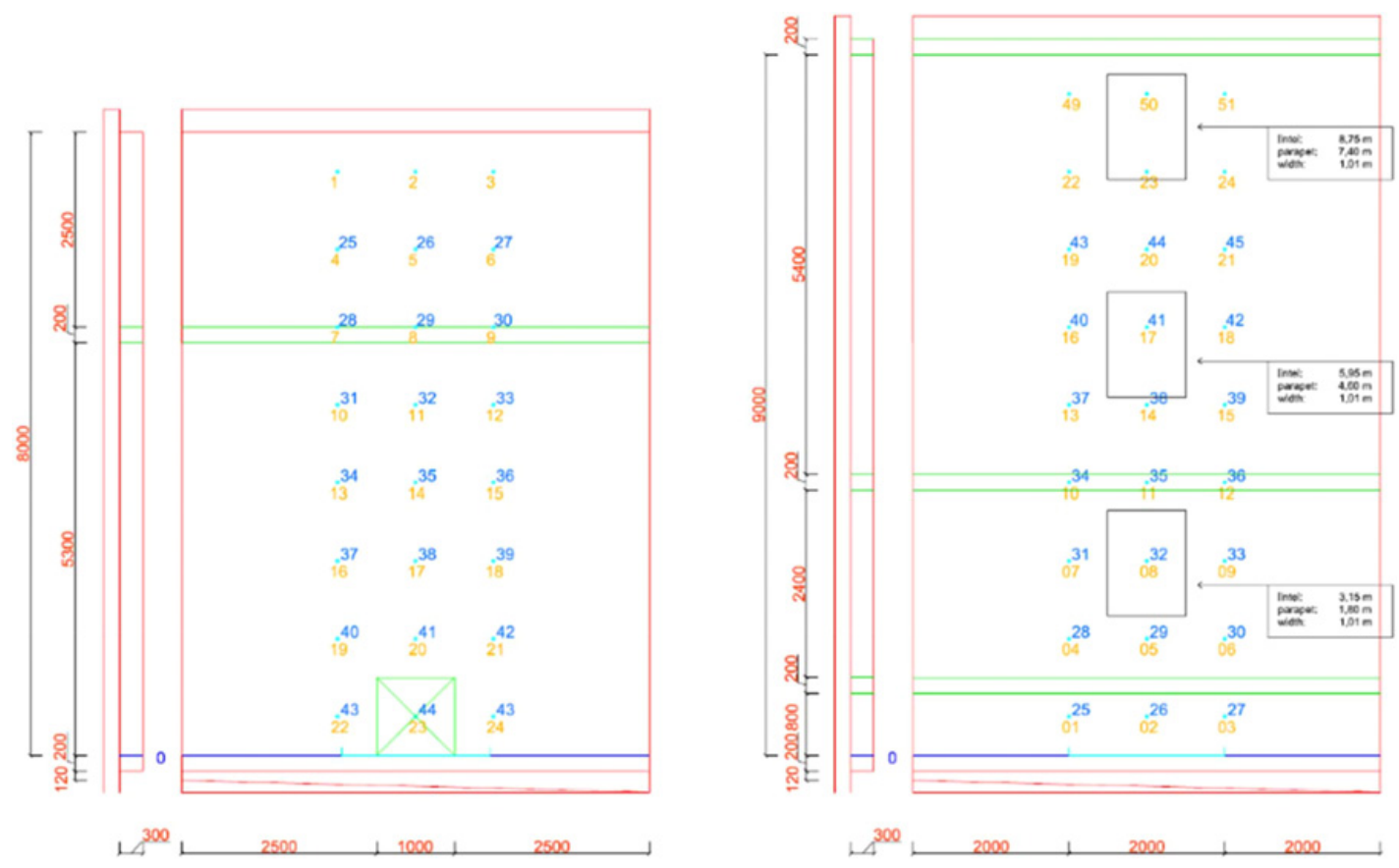

thermocouple in the facade $s=150 \mathrm{~mm}$ thermocouple on the facade $s=10 \mathrm{~mm}$

Figure 10. Schematic measurement plan of the first large-scale fire test (left) and the fourth large-scale fire test (right); bright: temperature measurement in front of the façade $(10 \mathrm{~mm})$, dark: temperature measurement at half depth of EPS $(150 \mathrm{~mm})$.

holes and corner configuration tested. A fire barrier was placed at a height of $5.30 \mathrm{~m}$. A schematic measurement plan is shown in Fig. 10. The façade surface has slight traces of fire but no significant damage. The façade did not open. The temperature maximum on the façade surface reached a value of approximately $825^{\circ} \mathrm{C}$. Inside the ETICS (at $150 \mathrm{~mm}$ depth of the EPS) the temperature maximum reached about $335^{\circ} \mathrm{C}$.

The second fire test was carried out in November 2014 and had the same façade structure as the first, only the fire load was changed to a 2001 isopropanol pool fire. The isopropanol pool is used to represent a job site scenario with burning and melting polystyrene and also a fire with a higher HRR see [5], for example a car. The ETICS opened in the twelfth minute and burned down completely shown in Fig. 11. A temperature was measured of above $1000^{\circ} \mathrm{C}$. A precise position of the thermocouple could not be assigned because of the destruction of the measurement grid.

After the second LS fire test an instruction paper by DIBt (German approval authority for a uniform fulfilment of technical tasks in the field of public law) which regulates the construction of the façade 
$2^{\text {nd }}$ International Seminar for Fire Safety of Facades, Lund (Sweden), 2016

Table 2. Overview about the large-scale fire test of the "Pilotprojekt EIFP" [1].

\begin{tabular}{|c|c|c|c|c|}
\hline Comment & LS Fire Test 1 & LS Fire Test 2 & LS Fire Test 3 & LS Fire Test 4 \\
\hline Date & 20.08 .2014 & 03.11 .2014 & 19.05 .2015 & 01.09 .2015 \\
\hline \multicolumn{5}{|l|}{$1 \mathrm{~min}$} \\
\hline \multicolumn{5}{|l|}{$5 \mathrm{~min}$} \\
\hline \multicolumn{5}{|l|}{$10 \mathrm{~min}$} \\
\hline \multicolumn{5}{|l|}{$15 \mathrm{~min}$} \\
\hline $20 \mathrm{~min}$ & & & & $\begin{array}{l}\text { Cancelled within } \\
12^{\text {th }} \text { Minute }\end{array}$ \\
\hline \multicolumn{5}{|l|}{$25 \mathrm{~min}$} \\
\hline \multicolumn{5}{|l|}{$30 \mathrm{~min}$} \\
\hline \multicolumn{5}{|l|}{$35 \mathrm{~min}$} \\
\hline $\begin{array}{l}\text { Condition of the } \\
\text { plaster layer }\end{array}$ & $\begin{array}{c}\text { In the area of } \\
\text { primary flame } \\
\text { decomposed and } \\
\text { burned }\end{array}$ & Destroyed & $\begin{array}{l}\text { Destroyed in flame } \\
\text { area/ decomposed } \\
\text { and burned }\end{array}$ & Destroyed \\
\hline $\begin{array}{l}\text { Condition of the } \\
\text { ETICS }\end{array}$ & $\begin{array}{l}\text { Polystyrene in } \\
\text { flaming area } \\
\text { decomposed }\end{array}$ & Almost destroyed & $\begin{array}{l}\text { Damaged in main } \\
\text { components }\end{array}$ & $\begin{array}{c}\text { Façade burning until } \\
\text { cancel through fire } \\
\text { brigade }\end{array}$ \\
\hline $\begin{array}{l}\text { Condition of fire } \\
\text { barrier }\end{array}$ & Not damaged & Not damaged & Not damaged & Not damaged \\
\hline Comment & No fire propagation & $\begin{array}{c}\text { Fire propagation to } \\
\text { the upper end of } \\
\text { façade }\end{array}$ & $\begin{array}{c}\text { No fire propagation } \\
\text { about middle fire } \\
\text { barrier until } 30 \\
\text { minutes }\end{array}$ & $\begin{array}{c}\text { Fire propagation to } \\
\text { the upper end of } \\
\text { façade }\end{array}$ \\
\hline
\end{tabular}



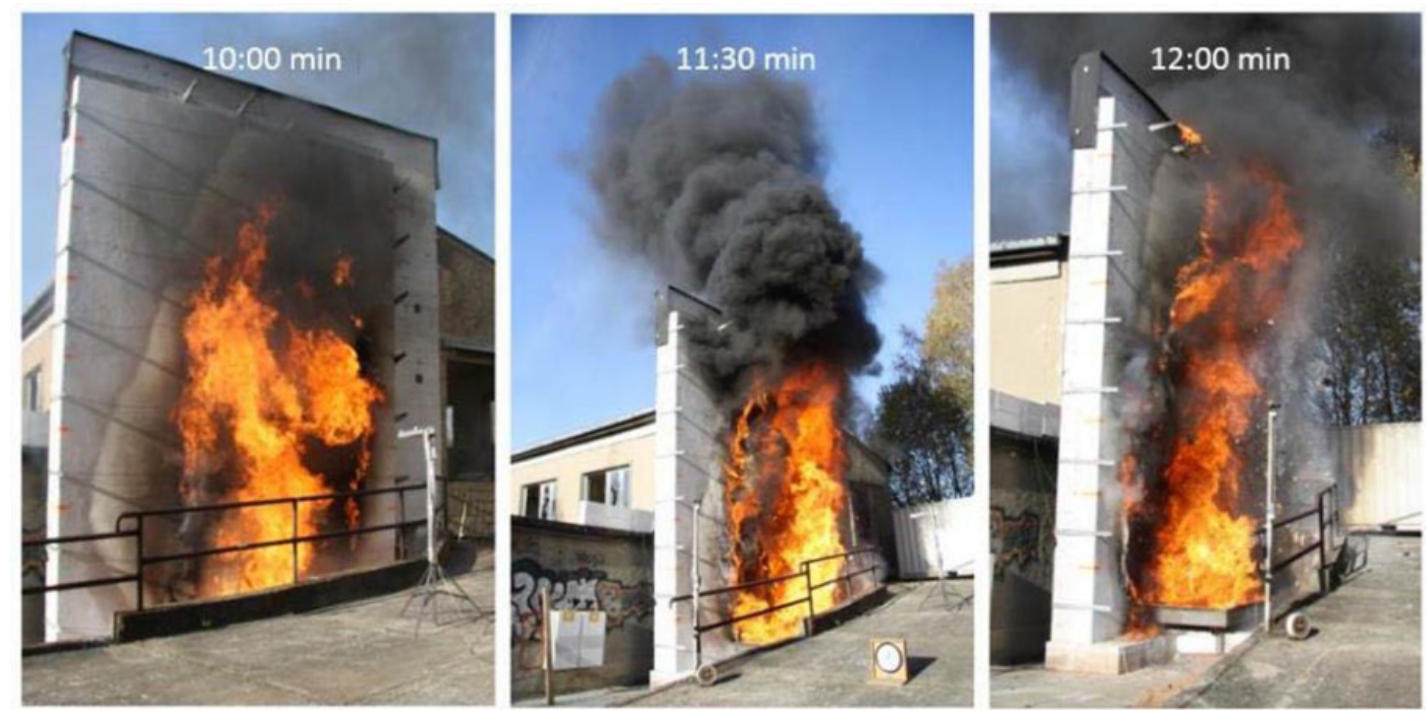

Figure 11. Second large-scale fire test, left: complete detachment of the plaster layer, middle: opening of the ETICS, right: burning fragments of the plaster layer and of melted EPS are thrown away.

design was issued [6]. The third test was planned considering [6]: one fire barrier at the transition from the base of the façade (made of XPS) to the main façade (made of EPS) at $0.80 \mathrm{~m}$. A second fire barrier at the height of the first floor ceiling at $3.40 \mathrm{~m}$ and a third at the height of the third floor ceiling at $9.00 \mathrm{~m}$, shown in Fig. 10 like it was made for the fourth test. The fire barriers were also secured with dowels. Within the third test carried out in May 2015, the façade opens first at about 30 minutes until the second fire barrier. The second opening happened during the $40^{\text {th }}$ minute with the result of a completely damaged façade. Compared with the second test the measures suggested in [6] seem to delay the vertical fire spread significantly. Until the $30^{\text {th }}$ minute temperature peaks of about $950{ }^{\circ} \mathrm{C}$ on the façade surface and about $450{ }^{\circ} \mathrm{C}$ inside the insulation were measured.

To show the unknown influence of openings in the façade surface LS fire test four was carried out in September 2015. The façade structure was the same like fire test three but three additional openings were made. The window lintel of the first opening was at a height of $3.15 \mathrm{~m}$, the second at a height of $5.95 \mathrm{~m}$ and the third at $8.75 \mathrm{~m}$ height. All openings has a size of $1.35 \mathrm{~m} \times 1.01 \mathrm{~m}$ (height by width). The influence of the three openings was obvious and the fourth fire test was cancelled within the twelfth minute by the fire brigade. In Fig. 12 problems with the lintel in the openings are illustrated. The temperature maximum on the façade surface reached a value of approximately $1300^{\circ} \mathrm{C}$. Inside the ETICS, the temperature maximum reached about $1050^{\circ} \mathrm{C}$ until the opening of the façade. After the test it can be shown that the fire barriers are not damaged. The strong fire behaviour seems to be attributable to the early fail of the construction of the edges of the window lintels. The structural design of the edges was performed according to the manufacturer's instructions and the edges/ brackets were made of plastic.

\section{LESSONS LEARNED AND PERSPECTIVES}

The fire tests show that the fire load at the base of a façade is a decisive influence factor for the fire behaviour of the façade. With job-site scenarios or special circumstances, pool-fires could be realistic fire-loads for example melted and burning EPS. An additional use of non-combustible fire barriers in 

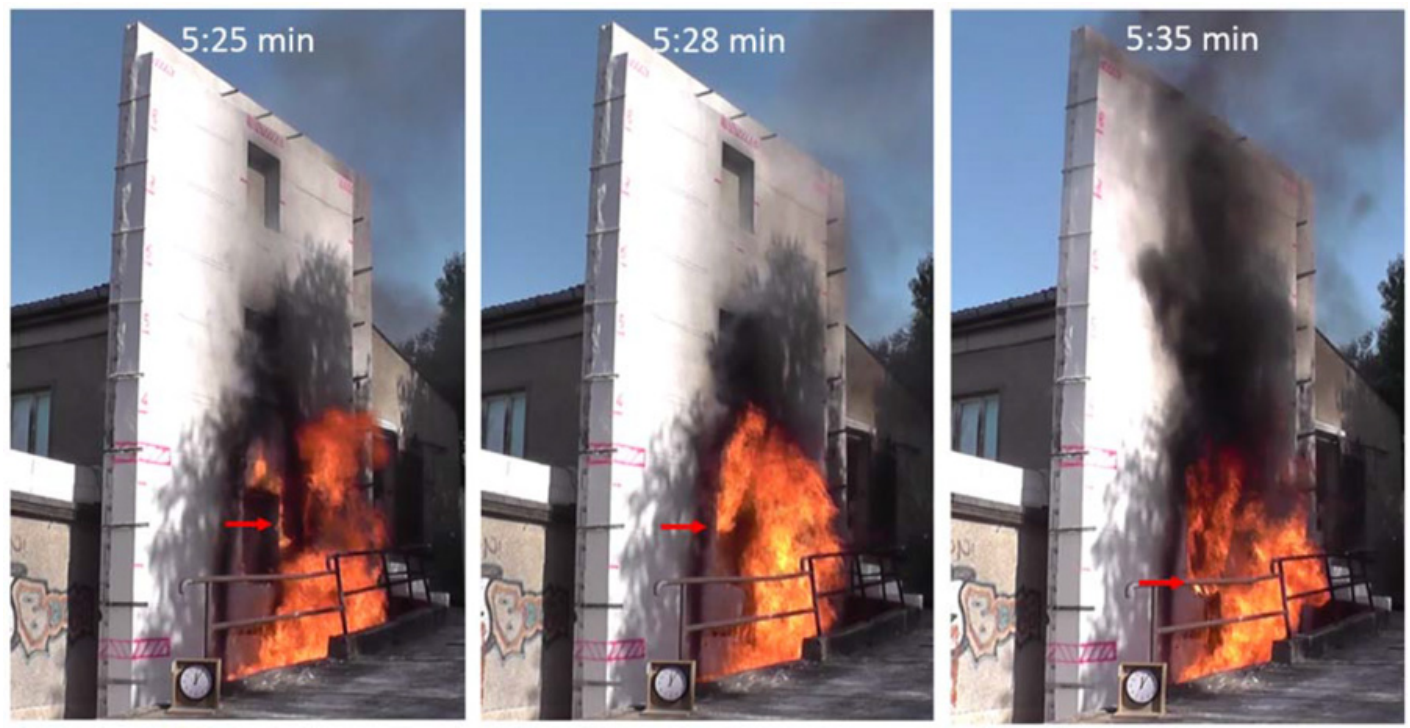

Figure 12. Fourth large-scale fire test, left: burning of the edge profiles of the lintel, middle: exit from burning EPS, right: burning of the entire window opening.

comparative setups promotes an increased level of safety. The job-site tests are carried out by a higher fire-load (about 3.5 MW) than the wood crib (about $2 \mathrm{MW}$ ).

Based upon the third test with an equal façade setting and fire-load the fourth test differed through additional openings like windows and shows that the type of façade design or structure can have an influence on the burning behaviour.

More detailed information about the fire tests can be found in [5] and [7] and a complete and detailed description of each fire test is given by the part reports of each fire test and the final report of the research project [1].

\section{References}

[1] Zehfuß, J.; Riese, O; Northe, C.; Küppers, J.; Pilotprojekt EIFP: Brandverhalten von Fassaden; January 2016 (previously unreleased).

[2] Babrauskas, V.; Grayson, S. J.; Heat Release in Fires, Elsevier Applied Science, 1992.

[3] DIN 18230-3:2002-08. Baulicher Brandschutz im Industriebau - Teil 3: Rechenwerte.

[4] Babrauskas, V; Heat Release Rates; In: Hurley, M. (Editor), SFPE Handbook of Fire Protection Engineering; Fifth Edition; Springer New York, 2016.

[5] Zehfuß, J.; Riese, O.; Northe, C.; Küppers, J.; Experimentelle und numerische Erkenntnisse zum Brandverhalten von WDVS-Fassaden auf Polystyrol-Basis; In: Bauingenieur (90) 2015; Edition 12/2015; Springer VDI Verlag.

[6] DIBt, Hinweis WDVS mit EPS-Dämmstoff, 16. Dezember 2014.

[7] Northe, C.; Riese, O.; Experimentelle Untersuchungen von Bränden an Fassaden mit unterschiedlichen Brandlasten; In: Braunschweiger Brandschutz-Tage 2015; September 15.-16.2015; Heft 227. 